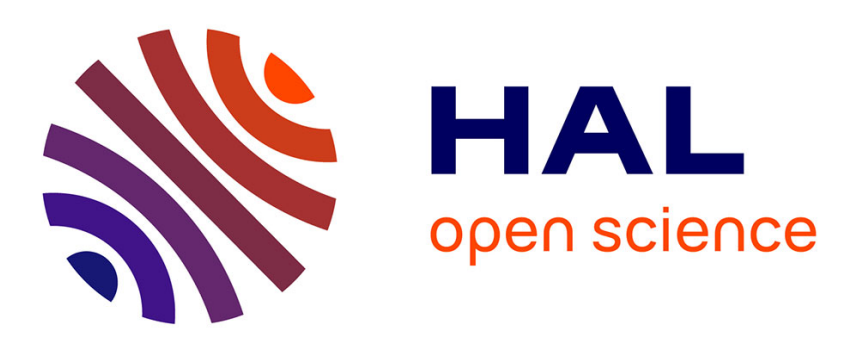

\title{
Residual vitellus and energetic state of wolf spiderlings Pardosa saltans after emergence from egg-sac until first predation
}

Aldana Laino, Mónica Liliana Cunningham, Fernando Garcia, M. Trabalon

\section{- To cite this version:}

Aldana Laino, Mónica Liliana Cunningham, Fernando Garcia, M. Trabalon. Residual vitellus and energetic state of wolf spiderlings Pardosa saltans after emergence from egg-sac until first predation. Journal of Comparative Physiology B, 2020, 190 (3), pp.261-274. 10.1007/s00360-020-01265-6 . hal02491402

HAL Id: hal-02491402

https://hal-univ-rennes1.archives-ouvertes.fr/hal-02491402

Submitted on 3 Jul 2020

HAL is a multi-disciplinary open access archive for the deposit and dissemination of scientific research documents, whether they are published or not. The documents may come from teaching and research institutions in France or abroad, or from public or private research centers.
L'archive ouverte pluridisciplinaire HAL, est destinée au dépôt et à la diffusion de documents scientifiques de niveau recherche, publiés ou non, émanant des établissements d'enseignement et de recherche français ou étrangers, des laboratoires publics ou privés. 
Aldana Laino, Mónica Liliana Cunningham, Fernando Garcia, M. Trabalon. Residual vitellus and energetic state of wolf spiderlings Pardosa saltans after emergence from egg-sac until first predation. Journal of Comparative Physiology B, Springer Verlag, 2020, 190 (3), pp.261-274. 〈10.1007/s00360$\underline{020-01265-6\rangle} .\langle$ hal-02491402〉

Authors'post-print

Editor's version available at the following: https://doi.org/10.1007/s00360-020-01265-6 
Residual vitellus and energetic state of wolf spiderlings Pardosa saltans after emergence from egg-sac until first predation

(1)

A. Laino ${ }^{1}$, M. Cunningham ${ }^{1}$, F. Garcia ${ }^{1}$, M. Trabalon ${ }^{2 *}$

1 - Instituto de Investigaciones Bioquímicas de la Plata "Prof. Dr. Rodolfo R. Brenner" (INIBIOLP), CCT-La Plata CONICET-UNLP, La Plata, Argentina

2 - Université de Rennes1, UMR-6552 CNRS EthoS, Rennes, France

* Correspondence: Marie Trabalon, Université de Rennes 1, UMR-6552 CNRS EthoS, Campus de Beaulieu, 263 avenue du Général Leclerc, CS 74205, 35042 Rennes Cédex, France. Tel: +33 223237101; e-mail: marie.trabalon@univ-rennes1.fr

\section{Acknowledgements}

The authors would like to thank Romina Becerra (INIBIOLP, Argentina) for her technical assistance, Sofia Romero for spider pictures, Dr Ann Cloarec and Rosana Del Cid for reading and correcting the English. The work was partly supported by funding from the project ECOS-MINCyT (France-Argentine) N A16B03. 
The aim of this study was to evaluate energetic source used by juveniles of a terrestrial oviparous invertebrate during the earliest periods of their life. Growth, behavioural activities and energy contents of Pardosa saltans spiderlings' residual vitellus were monitored during 8 days after their emergence from their egg-sac until they disperse autonomously. The life-cycle of juvenile after emergence can be divided into three periods: a gregarious while juveniles are aggregated on their mother, dismounting off their mother's back and dispersion. We present the first biochemical study of residual vitellus and energy expenditure during these three periods. At emergence, the mean weight of juveniles was $0.59 \mathrm{mg}$ and energy stock from residual vitellus averaged $51 \mathrm{cal} / \mathrm{g}$ wet mass. During gregarious period, the weight of the juveniles aggregated on their mother did not vary significantly and juveniles utilized only 1 cal/day from their residual vitellus. During the period from dismounting until their first exogenous feed, juveniles lost weight and used $30 \%$ of their residual vitellus stock. Proteins from the residual vitellus contributed principally to their energy expenditure during this period: $1.5 \mu \mathrm{g}$ protein/day. Juveniles' first exogenous feeding was observed 7-8 days after emergence, when $70 \%$ of residual vitellus energy had been utilized. Juveniles dispersed after eating, reconstituting an energy stock comparable to that observed at emergence from egg-sac (50 cal/g wet mass). This new energy stock contains mainly lipids unlike the energy stock from the residual vitellus.

Keywords: Biochemical status, Post-hatching yolk, Energy utilization, Post-emergence periods, Arachnids 


\section{Introduction}

Viviparous animals develop thanks to regular nutritional contribution via maternal paths during pre-natal development. At birth, these newborns have limited energy reserves and need rapid access to exogenous food to maintain their homeostasis and survive. The first food intake usually occurs within one hour of birth. Thus, all mammalian neonates need colostrum and milk rich in nutrients (proteins, lipids, and carbohydrates) to reconstitute quickly a favourable energetic state for survival (Nowak 1996; Nowak and Poindron 2006). The embryonic development of oviparous animals depends on the presence of energy reserves in the egg, the vitellus (or yolk) which is the exclusive nutrient source. Vitellus contents (lipids, proteins and carbohydrates) are transferred during this period from the vitellus sac to the embryonic circulation as lipoprotein particles (Lambson 1970), thus they are internalized into the abdominal cavity during the last days of incubation (Noble and Ogunyemi 1989). The eggs contain a large quantity of vitellus which is more than required for their embryologic development. The unutilized vitellus (or "residual vitellus") is attached to the hatchlings at hatching and provides energy to the newborn during the initial non-feeding period (Marlen and Fisher 1999). The residual vitellus of most hatchling birds is supplemented by exogenous nutrition provided by the parents throughout the time their offspring remain in the nest (Chappell et al. 1993). Some pseudoscorpion and spider mothers provide their juveniles with a supplement in the form of trophic eggs (Kim 2000) or energetic fluid (Brach 1978; Han Malthiesen 1993). For example, Taxeus magnus (Salticidae) juveniles after emergence from the eggs-sac are nourished in the nest until dispersion with a secretion ("milk") secreted by their mother's epigastria furrow (Chen et al. 2018). In contrast, other oviparous hatchlings completely rely on their residual vitellus (the first feeding only occurs after the residual vitellus has been exhausted) and/or their ability to capture prey in order to satisfy their energy 
demands after hatching (Kraemer and Bennett 1981; Rowe 2018; Venkatesan et al. 2005). For example, young Betta splendens fishes remain in the paternal nest after hatching and, when the residual vitellus is completely absorbed two days after, they leave the paternal nest and disperse in search of food (Bronstein 1982). The first feeding of sedentary and wandering arthropods, like many scorpions and spiders, by cannibalism, predation or matriphagy are observed several days or even weeks after hatching at the beginning of the dispersion period (Farley 2005; Kim and Horel 2010; McAlister 1960; Polis 1990; Pourié and Trabalon 1999; Ruhland et al. 2016a, b; Van Der Hammen 1978; Weygoldt 2013; Williams 1969).

Investigations of hatching residual vitellus and energy contents have been restricted to a few vertebrate species (birds: Ar et al. 1987; Chappell et al. 1993; Noy and Sklan 1998, 1999; reptiles: Allsteadt and Lang 1994; Congdon and Gibbons 1989; Qu et al. 2019; Radder et al, 2007; Venkatesan et al. 2005). These studies revealed that the amount of residual vitellus available at hatching vertebrates varies considerably among vertebrate species because a minor variation in the incubation temperature affects energy reserves (Radder et al. 2007). Information on hatchling residual vitellus and energetic state for other terrestrial oviparous arthropods exists only for the insect Adalia bipunctata (Sloggett and Lorenz 2008) and in the spider Pardosa saltans (Trabalon et al. 2017). This is surprising as arthropods provide excellent models for different reasons: (i) juveniles of numerous species start eating by themselves several days after hatching as some reptiles; ii) the amount of residual vitellus is less sensitive to minor variations in the natural environment contrary to oviparous vertebrates. Residual vitellus utilization by hatchling arthropods, spiders in particular, is not known. So, we monitored the quantity and quality of total residual vitellus in terrestrial spiders' eggs during the earliest periods of a juvenile's life. We hypothesized that juveniles would use total 
residual vitellus in the eggs during the earliest periods of their life, before they had the opportunity of gathering significant energy resources from their own feeding behavior.

We selected the free-moving wolf spider, Pardosa saltans, as our model of arthropod species. These terrestrial spiders live in forests, woodlands and copses and sometimes in nearby grasslands and hedgerows (Ruhland et al. 2016 a, b). After emergence from the eggsac, juveniles which do not eat any exogenous food while they are carried by their mothers (gregarious period), they dismount gradually off their mother and disperse after their first predation (Ruhland et al. 2016b). A recent report (Trabalon et al. 2017) described the biochemical characteristics of the vitellus and the evolution of the energetic state of $P$. saltans' eggs during embryonic development. Carbohydrates are a minor constituent of vitellus, while proteins are predominant in $P$. saltans' lipovitellins which are also present in the insect A. bipunctata (Sloggett and Lorenz 2008). The energetic stock provided by $P$. saltans mothers to their eggs is important and enables young to develop and emerge with 38 $\%$ of the initial energy stock of the vitellus (Trabalon et al. 2017). Therefore, we investigated juveniles' energy expenditure to assess their energetic cost while they were aggregated on their mother until their first exogenous feed by predation or cannibalism once they had dismount off their mother's back.

Our aim was three-fold: first, to identify the different stages (gregarious, dismounting and dispersed juveniles) after emergence from egg-sac until first exogenous feeding (predation or cannibalism); second, to evaluate variations of residual vitellus contents (proteins, carbohydrates and lipids) and juveniles' calorie stocks after emergence until they capture their first prey and disperse; and third, to evaluate the contributions of proteins, carbohydrates, and triglycerides from residual vitellus to the maintenance of juveniles' energy until catching their first prey. We hypothesized that: i) all the initial calorie stock from residual vitellus is used 
while aggregated on their mother; ii) lipids (glycerides) and carbohydrates of residual vitellus are the energy source used in priority during this period; iii) the first exogenous feeding and dispersion is related to total residual vitellus depletion.

\section{Materials and methods}

\section{Ethics statement}

Our research conformed to legal requirements and guidelines established for the treatment of animals in research using invertebrate species and for their care using accepted ethical laboratory standards. The species used for the experiments is not endangered or protected.

\section{Spider rearing and experimental groups}

Our subjects were young adult females captured during the copulation period in a forest near the Paimpont biological station (property of the University of Rennes 1; France; 48 00'05.67" North, 2 ${ }^{\circ} 13^{\prime} 46.65^{\prime}$ "West) in April-June 2018. Females were housed individually in circular terrariums $(10 \mathrm{~cm}$ diameter $\mathrm{x} 5 \mathrm{~cm}$ high) without any substrate on bottom and were kept at $20 \pm 1^{\circ} \mathrm{C}$, with $57 \pm 1 \%$ relative humidity under an L:D, 14:10 h photoperiodic cycle. Spiders were fed every other day ad libitum, with either cricket (Acheta domestica and Nemobius sylvestris) or adult flies (Drosophila melanogaster).

All females were checked at least twice a day (morning and evening) in the laboratory to record emergence of juveniles from egg-sacs. One experiment evaluated, each day, numbers, mortality and weight of juveniles before emergence until dispersion $(\mathrm{N}=340$ juveniles from 20 egg-sacs), and a second experiment analysed changes of juveniles' energetic state before emergence until dispersion of juveniles ( $\mathrm{N}=200$ juveniles/ages from 100 egg-sacs).

\section{Number and Weight of juveniles}


Juveniles' weights were recorded just after they had emerged from the egg-sac (12 h after emergence from egg-sac; D0) then after 1 (D1), 2 (D2), 3 (D3), 4 (D4), 5 (D5), 6 (D6), 7 (D7) and 8 (D8) days. All spiders were transferred individually into an Eppendorf tube (1.5 mL) and anesthetized by chilling at $7^{\circ} \mathrm{C}$ for $5 \mathrm{~min}$ before being reserved. Mothers were separated from juveniles on micrographs and replaced in their terrarium. Juveniles were weighed using a Sartorius electronic balance ( $\pm 0.01 \mathrm{~g}$; Palaiseau, France). All juveniles on their mother's body were weighed as a group and then counted. All juveniles that had dismounting or dispersed were counted and weighed individually. After being weighed, juveniles were returned to their appropriate mother in their terrarium. All spiders survived anesthesia and were separated from their mother for less than $5 \mathrm{~min}$. Juveniles locomotor activity was recorded for $30 \mathrm{~min}$ after their reintroduction into their terrarium.

\section{Behavioural period and energetic state}

To assess energetic state changes, 100 mothers with their egg-sacs were divided randomly into five groups of 20 females each: just after hatching of juveniles (D0), and on 2 (D2), 4 (D4), 6 (D6) and 8 (D8) days after hatching. All D0 and D2 juveniles aggregated on their mother were counted and transferred individually into an Eppendorf tube and were frozenkilled at $-18^{\circ} \mathrm{C}$. Only D4 and D6 juveniles dismounted off their mother's back and dispersed D8 juveniles were transferred individually into an Eppendorf tube and were freeze-killed at $18^{\circ} \mathrm{C}$. After being weighed, each juvenile was mixed in $50 \mu \mathrm{L}$ of water, homogenised ( $5 \mathrm{~min}$ ), vortexed for $30 \mathrm{~min}$ and centrifuged at $10,000 \mathrm{rpm}$ for $10 \mathrm{~min}$ at $5^{\circ} \mathrm{C}$. Three aliquots $(10$ $\mu \mathrm{L} /$ aliquot) of supernatant were taken to assay carbohydrates and proteins. Lipids from the homogenate sample were extracted with $600 \mu \mathrm{L}$ of methanol-dichloromethane (v:v; 1:2) (Sigma, Saint-Quentin Fallavier, France), vortexed for $30 \mathrm{~min}$ and centrifuged at 10,000 rpm, for $10 \mathrm{~min}$ at $4{ }^{\circ} \mathrm{C}$. The pellets were discarded and the supernatant was aliquoted for further 
analyses. We triplicated the analysis of each sample and then calculated the ratio of proteins, lipids and carbohydrates related to wet mass. Energetic state was assessed from 20 extracts for each age group.

\section{Quantification of proteins and lipoproteins from residual vitellus}

Total protein content in a $10 \mu \mathrm{L}$ biological sample for each age (D0 to D8) was determined according to Bradford's method (1976) with a Coomassie protein assay kit (Thermo Scientific, Cergy Pontoise, France) using bovine serum albumin as the standard. We divided the protein level data by fresh weight to obtain concentrations in $\mu \mathrm{g} \cdot \mathrm{mg}^{-1}$. Proteins were separated by SDS-PAGE electrophoresis using a gradient of 4-12\% acrylamide (Laemmli 1970), $25 \mu \mathrm{g}$ of protein of each experimental group were loaded per well, and after resolution the gels were stained with Coomassie Brilliant Blue R-250 (Sigma Chemical Co., St. Louis, MO). The respective molecular weights were calculated. Electroblotting was carried out for 1 h at $100 \mathrm{~V}$ (Trans-Blot SD Semi Dry Transfer Cell, Bio-Rad Laboratories, Hercules, CA, USA) from the unstained gel to nitrocellulose membranes using $48 \mathrm{mM}$ Gly, $39 \mathrm{mM}$ Tris, $\mathrm{pH}$ 9.2, 20\% MeOH buffer (Laino et al. 2011; Trabalon et al. 2017). After being blocked overnight at $4{ }^{\circ} \mathrm{C}$ with $3 \%$ (w/v) non-fat dry milk in $0.15 \mathrm{M} \mathrm{NaCl}, 10 \mathrm{mM}$ Tris- $\mathrm{HCl}, \mathrm{pH}$ 7.4, the membranes were incubated for $2 \mathrm{~h}$ with the primary antibodies against purified lipovitellin of Schizocosa malitiosa (1:1000), as used by Trabalon et al. (2017). Specific antigens were detected by goat anti-rat. IgG horseradish peroxidase conjugate (1:5000) immunoreactivity was visualized by enhanced electrochemiluminescence (ECL). The signals emitted for chemiluminescence were detected using Chemidoc Imaging System (Bio-Rad) and analysed using Image J Software (NIH). The results of the densitometry are expressed in percentages: the bands corresponding to juveniles 2 days before emergence from egg-sac (D-2) were taken as $100 \%$ for embryonic lipovitellin. 
Lipids were extracted from juveniles following Trabalon et al.' procedure (2017). Lipids

were evaluated quantitatively by thin-layer chromatography (TLC) coupled to a flame ionization detector in an Iatroscan apparatus model TH-10 (Iatron Laboratories, Tokyo, Japan), after separation on Chromarods type S-III (Ackman et al. 1990; Laino et al. 2011). The general procedure for separation and identification of lipids has been described previously by Cunningham and Pollero (1996) and Trabalon et al. (2017).

Total triglycerides in a $10 \mu \mathrm{L}$ biological sample were assessed using a colorimetric method (Triglycerides-test, Randox, Crumlin, County Antrim, UK). Triglycerides were determined after enzymatic hydrolysis with lipases. The indicator was a quinoneimine formed from hydrogen-peroxide, 4-aminophenazone and 4-chlorophenol under the catalytic influence of peroxidase. We divided triglyceride level data by fresh weight to obtain concentrations in $\mu \mathrm{g} \cdot \mathrm{mg}^{-1}$.

Cholesterol in a $10 \mu \mathrm{L}$ biological sample was determined after enzymatic hydrolysis and oxidation using a colorimetric method. The indicator quinoneimine is formed from hydrogenperoxide and 4-aminoantipyrine in the presence of phenol and peroxidase (Cholesterol-test, Randox, Crumlin, County Antrim, UK). We divided the cholesterol level data by fresh weight to obtain concentrations in $\mu \mathrm{g} \cdot \mathrm{mg}^{-1}$.

\section{Quantification of carbohydrates and free glucose from residual vitellus}

Total carbohydrate concentration in a $10 \mu \mathrm{L}$ homogenate sample was assessed using a colorimetric method (Total Carbohydrate Assay kit, Sigma-Aldrich, St Louis, USA) based on the phenol-sulfuric acid method in which polysaccharides are hydrolyzed and then converted into furfural or hydroxylfurfural with a yellow-orange colour as a result of the interaction 
between the carbohydrates and the phenol. We divided the carbohydrate level data by fresh weight to obtain concentrations in $\mu \mathrm{g} \cdot \mathrm{mg}^{-1}$.

Free glucose concentrations in a $10 \mu \mathrm{L}$ homogenate sample were determined using a colorimetric method after enzymatic oxidation in the presence of glucose oxidase (Glucosetest, Randox, Crumlin, Co, Antrim, UK). The hydrogen peroxide formed reacted in the presence of peroxidase with phenol and 4-aminophenazone to form a red-violet quinoneimine dye as the indicator. We divided the free glucose levels data by fresh weight to obtain concentrations in $\mu \mathrm{g} \cdot \mathrm{mg}^{-1}$.

\section{Energetic equivalent of proteins, lipids and carbohydrates}

We estimated the total calories provided by different energy substrates (proteins, lipids and carbohydrates) using Beningher and Lucas's (1984) conversion factors applied to arthropods (Garcia-Guerrero et al. 2003; Heras et al. 2000; Laino et al. 2013; Trabalon et al. 2017). The conversion factors were: $4.3 \mathrm{kcal} / \mathrm{g}$ for proteins, $7.9 \mathrm{kcal} / \mathrm{g}$ for lipids, and $4.1 \mathrm{kcal} / \mathrm{g}$ for carbohydrates.

\section{Statistical analyses}

Statistical analyses were performed using STATISTICA 6.0 for WINDOWS (Statsoft Inc.). As all our data met the requirements for parametric statistics, we analysed ours using one-way ANOVAs. When differences between means were significant at the $p<0.05$ level, post-hoc Tukey' tests (HSD) were applied. Results are expressed as means \pm SE.

\section{Results}

\section{Numbers, weight, mortality and behavioral activity of juveniles}


Emergence of juveniles (Fig.1A) and climbing onto the females' body lasted approximately $12 \pm 1 \mathrm{~h}$ (juveniles D0), mothers abandoned their egg-sac after emergence of all the juveniles $(45.1 \pm 8.5$ young). The juveniles of one egg-sac covered all a female's opisthosoma and prosoma, forming a dense aggregate lasting 2 days while silk threads connected the young to their mother's body (Fig. 1A, 1B; 2A). Juveniles that fell off did not climb back on their mother but remained attached to her legs. During the next three days (Fig. $1 \mathrm{C} ; 2 \mathrm{~A}$ ), the juveniles gradually dismounted off their mother but remained grouped near her (34\% at D3 and $90 \%$ at D6). Juveniles' locomotor activity increased gradually during this dismounting period and their aggregation became less dense. The first predation by dispersed juveniles was observed on D7. D8 juveniles occupied all the terrarium, moving away one from the other. These D8 juveniles captured small prey (Fig. 1C) and led a free life away from their mother (Fig. 1D). Some cases of cannibalism D8 juveniles (10\%) were observed.

Number and weights of juveniles changed significantly in the behavioural period: aggregated on a mother's back, dismounting off mother's back and dispersion $\left(\mathrm{F}_{(14,325)}=2.74\right.$, $\mathrm{p}=0.0064$ and $\mathrm{F}_{(14,325)}=5.08, \mathrm{p}=0.0068$, respectively; Fig. $\left.2 \mathrm{~B}\right)$. During the first two days of aggregation on a mother's back, $14 \%$ of juveniles died or disappeared and weight of juveniles aggregated on a mother's back did not change significantly with ages until D5 $\left(F_{(5,184)}=0.68, p=0.56\right)$. During dismounting off their mother's back, $63 \%$ of juveniles died or disappeared and dismounted D3 and D4 juveniles weighed significantly more than dismounted D5 and D6 juveniles: $0.55 \pm 0.02$ for D3 vs $0.46 \pm 0.01 \mathrm{mg}$ for D6 $\left(\mathrm{F}_{(5,130)}=3.30\right.$ $, p=0.024)$. During dispersion period, weights of dispersed juveniles were significantly lower before predation: $0.47 \pm 0.01$ for D6 than after predation $0.52 \pm 0.03 \mathrm{mg}$ for D7 and D8 after predation $\left(\left(\mathrm{F}_{(2,51)}=3.42, \mathrm{p}=0.024\right.\right.$; Fig. $\left.2 \mathrm{~B}\right)$ and only $33 \%$ of juvenile were still alive 8 days after emergence. 
254

255

256

257

258

259

260

261

262

263

264

265

266

267

268

269

270

271

272

273

274

275

276

Protein levels in D0 juveniles averaged $6.97 \pm 0.70 \mu \mathrm{g} . \mathrm{mg}^{-1}$ wet mass (Fig. 3A), decreased significantly during the dismounting period (i.e $1.69 \pm 0.50 \mu \mathrm{g} \cdot \mathrm{mg}^{-1}$ in D6) and increased significantly on D8 after the first exogenous feeding and dispersion $\left(\mathrm{F}_{(4,96)}=9.79\right.$, $\mathrm{p}<$ 0.0001).

Analyses of images of dissociating electrophoresis and immunoblot analyses of juveniles' proteins, taking as reference the previously described stage of juveniles hatching from egg inside the egg-sac (Trabalon et al., 2017), revealed the presence of different bands on 1-D gels visualised by blue staining (Fig. 3B). No significant differences could be evidenced concerning the values of bands between duplicate gels, showing the reproducibility of the experiments. Four protein bands were identified during the embryonic developmental stages of P. saltans (Trabalon et al. 2017): protein bands 116, 87, 70, and $42 \mathrm{kDa}$ (Fig. 3B; Table 1) corresponded to lipovitellins (Fig. 3B). These proteins were present in hatchling juvenile (D2) inside the egg-sac. The 116 and $87 \mathrm{kDa}$ proteins were consumed during post-embryonic development by D-2 inside the egg-sac, and only the 70 and $42 \mathrm{kDa}$ protein bands were present in D0 juveniles emerging from the egg-sac. The $70 \mathrm{kDa}$ protein represented $74 \%$ of the lipovitellin in D0 juveniles and this protein was consumed progressively until dispersion (Fig. 3B). The $42 \mathrm{kDa}$ protein represented $26 \%$ of the lipovitellin in D0 juveniles and was rapidly consumed during the aggregated period (Table 1).

\section{Lipid levels from residual vitellus}

Glycerides (diglycerides and triglycerides), free fatty acids, phospholipids (phosphatidylcholine and phosphatidylethanolamine), sphingolipids (sphingomyelin), sterols (cholesterol) and hydrocarbons accounted for the main lipid content in residual vitellus of emerged juveniles. 
Glyceride levels varied significantly with time (Fig. 3). Triglyceride levels (D0: $2.26 \pm$ $0.19 \mu \mathrm{g} . \mathrm{mg}^{-1}$ wet mass; Fig. 4a) did not vary significantly between D0 and D4 but decreased significantly at the end of the dismounting period (D6: $1.10 \pm 0.58 \mu \mathrm{g} \cdot \mathrm{mg}^{-1}$ wet mass) and then increased significantly after the first exogenous feeding (D8: $3.74 \pm 0.52 \mu \mathrm{g}^{\mathrm{mg}} \mathrm{m}^{-1}$ wet mass $)\left(\mathrm{F}_{(4,96)}=7.04, \mathrm{p}<0.0001\right)$. Diglyceride and free fatty acid levels (Fig. 4B, C) on averaged $0.26 \pm 0.05 \mu \mathrm{g} \cdot \mathrm{mg}^{-1}$ and $1.06 \pm 0.02 \mu \mathrm{g} \cdot \mathrm{mg}^{-1}$ wet mass respectively. These compounds varied significantly with time $\left(\mathrm{F}_{(4,96)}=11.01, \mathrm{p}<0.0001\right.$ and $\mathrm{F}_{(4,96)}=41.72$, $\mathrm{p}<$ 0.0001, respectively): decreased significantly during the aggregated period (Tukey's test: D0 vs D2, p $<0.0001$ ), increased during the dismounting period (Tukey's test: D4 vs D6, p < 0.0001 for both) and then decreased significantly after dispersion on D8: $0.12 \pm 0.01 \mu \mathrm{g} . \mathrm{mg}^{-1}$ and $0.20 \pm 0.01 \mu \mathrm{g} \cdot \mathrm{mg}^{-1}$ wet mass, respectively (Tukey's test: D6 vs D8, $\mathrm{p}<0.0001$ for both).

Cholesterol levels on D0 averaged $0.59 \pm 0.05 \mu \mathrm{g} . \mathrm{mg}^{-1}$ wet mass (Fig. 5A) and increased significantly from D0 to D8 $\left(\mathrm{F}_{(4,96)}=2.64, \mathrm{p}=0.02\right)$, when cholesterol levels were significantly higher: $2.09 \pm 0.30 \mu \mathrm{g} \cdot \mathrm{mg}^{-1}$ (Tukey's test: D0 vs D8, $\mathrm{p}=0.0007$ ).

Phospholipids levels on D0 averaged $7.89 \pm 0.89 \mu \mathrm{g} \cdot \mathrm{mg}^{-1}$ wet mass (Figure 5B) and decreased significantly on D2 and D8 $\left(\mathrm{F}_{(4,96)}=37.46, \mathrm{p}<0.0001\right)$.

Hydrocarbon and sphingomyelin levels did not vary significantly from D0 until dispersion of juveniles $\left(\mathrm{F}_{(4,96)}=3.8\right.$ to $4, \mathrm{p}>0.05$; Table 2$)$.

\section{Carbohydrates and free glucose levels from residual vitellus}

Levels of carbohydrates averaged $0.76 \pm 0.06 \mu \mathrm{g} \cdot \mathrm{mg}^{-1}$ wet mass on D0 after emergence. Their levels were significantly lower on D6: $0.38 \pm 0.06 \mu \mathrm{g} \cdot \mathrm{mg}^{-1}$ wet mass $\left(\mathrm{F}_{(4,96)}=2.40, \mathrm{p}=\right.$ 0.031; Fig. 6A).

Free glucose levels averaged $0.11 \pm 0.01 \mu \mathrm{g} \cdot \mathrm{mg}^{-1}$ wet mass on D0 after emergence. Free glucose levels did not vary significantly until dispersion $\left(\mathrm{F}_{(4,96)}=1.881, \mathrm{p}=0.147\right.$; Fig. $\left.6 \mathrm{~B}\right)$. 
Just after emergence (Fig. 7), the total caloric content of D0 juvenile was $51 \pm 5$ cal.g ${ }^{-1}$ wet mass, the energy equivalent of which was represented mainly by proteins (59\%) supplemented by lipids (35\%), and carbohydrates (6\%). During the aggregated period, only $6 \%$ of the energy stock was used by immobile D0 and D2 juveniles transported by their

306 mother. During the dismounting period, active D4 and D6 juveniles used $66 \%$ of their energy stock before their first predation, and D6 juveniles' energetic stock was significantly lower than at the other ages (ANOVA: $\mathrm{F}_{(4,96)}=6.53, \mathrm{p}<0.0001$; Tukey test: D0 vs D6, $\mathrm{p}<0.0001$ ) and its energy equivalent was mainly due to lipids (50\%), proteins (42\%) and carbohydrates (8\%). D8 juvenile reconstituted they energy stock rapidly after predation $\left(48 \mathrm{cal.g}^{-1}\right)$ and its energy equivalent was mainly due to lipids $(61 \%)$, proteins $(33 \%)$ and carbohydrates $(6 \%)$.

\section{Discussion}

Our results confirmed that $P$. saltans juveniles emerged from an egg-sac with an important residual vitellus as vertebrate hatchlings do (Congdon and Gibbons 1989; Webb et al. 1986). This residual vitellus is their exclusive nutrient source until their first exogenous feeding and corresponds to an energetic stock of $50 \mathrm{cal} / \mathrm{g}$ wet mass. The vitellus of newly emerged juveniles is predominantly composed of proteins and lipids as in the egg yolks of hatchling oviparous vertebrates (Venkatesan et al. 2005) and invertebrates (crustaceans: Chen et al. 2004; Garcia et al. 2006; Kawazoe et al. 2000; Lubzens et al. 1997; insects: Chino 1997; Dhadialla and Raikhel 1990; Tufail and Takeda 2008; arachnids: Boctor and Kamel 1976; Chinzei et al. 1983; Laino et al. 2011, 2013; Tatchell 1971; Trabalon et al. 2017). This energetic stock was utilized by $P$. saltans juveniles after emergence until their first exogenous feeding, but only $33 \%$ of the juveniles survived until dispersal, as all species with an "r" reproduction strategy (Mac Arthur and Wilson 2001; Planka 1970). 
The use of the energy reserve from the yolk is negligible during the aggregated period. During this period, the juveniles remain motionless on their mother's body for 3 days, do not lose weight, and use only $7 \%$ of their energy stock ( 1 cal from residual vitellus/day). This energy expenditure can be interpreted as corresponding to the energy expenditure made by their basal metabolism to maintain the living organism.

Conversely, when the juveniles are no longer transported by their mother, their locomotor activity is important as it is that of young reptiles when they leave the nest and disperse (Carr and Ogren 1960). These activities are likely to enhance metabolic rates and increase energetic utilization by incurring the use of $11 \mathrm{cal} / \mathrm{g}$ wet mass/day. As a result, these juveniles lost weight and their energy stock dropped significantly.

P. saltans juveniles' first exogenous feed (predation or cannibalism) was observed 7-8 days after emergence, when $70 \%$ of residual vitellus energy had been utilized but before total vitellus depletion.

Juveniles dispersed after eating and reconstituted an energy stock comparable to that observed during emergence from egg-sac $(50 \mathrm{cal} / \mathrm{g}$ wet mass), but the lipid/protein ratio was inversed. This new energy stock contains mainly lipids unlike the energy stock from the residual vitellus.

\section{Contributions of lipovitellin from residual vitellus}

Lipovitellins are complex glyco-lipoproteins found in oviparous animals' eggs. The main source of energy used by emerged juveniles comes from proteins not lipids, contrary to our hypothesis. Thus levels of total proteins decreased gradually and $76 \%$ of the protein stock was used by juveniles before their first exogenous feeding. This priority use of proteins, and more precisely lipovitellins, by juveniles is comparable to that observed during the embryonic 
development of $P$. saltans (Trabalon et al 2017) and in oviparous vertebrate species (Silas et al. 1984). Lipovitellin is composed of four apolipoproteins of 116, 87, 70 and $42 \mathrm{kDa}$, respectively and represents $35-45 \%$ of the total protein in juveniles $P$. saltans before emergence from their egg-sac. The antibody recognized subunits of 70 and $42 \mathrm{kDa}$, from very early embryo stages, as previously seen in $P$. saltans (Trabalon et al. 2017). The presence of subunits of molecular weights similar to those described in the present work has been reported in the vitellogenic ovary and eggs of the spider Polybetes pythagoricus (Romero et al. 2019) and Tegenaria atrica (Pourié and Trabalon 2003). Bednarek et al. (2019) showed a link between the gene of vitellogenin of the spider Parasteatoda tepidariorum with the expression of the subunits of $47 \mathrm{kDa}$, confirming that these small subunits are not a product of the degradation of bigger subunits, but form part of the lipovitellins. Apolipoproteins are used selectively by juveniles over time. Thus peptides 116 and $87 \mathrm{kDa}$ are used completely before emergence. While juveniles are aggregated on their mother they use the totality of peptide 42 $\mathrm{kDa} .70 \mathrm{kDa}$ peptide is used slowly after emergence until first food intake and dispersion as in Ornithodoros moubata acari (Fagotto 1990). This decrease was linked to protease activation to generate peptides and aminoacids (Boctor et al. 1986; Chinzei and Yano 1985; Fagotto 1990).

Glycerides, principal lipids of residual vitellus, are used to store metabolic energy. Hydrolysis of the ester bonds results in the release of glycerol and fatty acids. This hydrolysis is the first step in lipolysis, which is followed by oxidation. Free fatty acids and cholesterol are transported by lipoproteins and phospholipids in vertebrates and invertebrates (Cunningham et al. 1994, Cunningham and Pollero 1996; Donohue et al. 2008; Fredrickson and Gordon 1958; Gudderra et al. 2002; Noga et al. 2002; Noga and Vance 2003; Spector 1984). The other lipids of residual vitellus are sphingomyelin, cholesterol and hydrocarbons. Sphingomyelin and cholesterol are co-located on the surface of lipoprotein particles (Slotte 
and Ramstedt 2007; Trabalon et al. 2017). Sphingomyelin regulates the distribution of cholesterol within membranes. Cholesterol plays an important role in arthropod physiology (Andersen 1979; Martin-Creuzburg et al. 2007; Merzendorfer and Zimoch 2003): cuticular surface, constituent of membranes in the lipid bilayer; precursor for the synthesis of steroid hormones involved in moulting (Trabalon and Blais 2012). P. saltans juveniles' cholesterol levels increased gradually with time until dispersion and these variations correspond to juveniles' needs for moulting (Cheong et al. 2015; de Almeida et al. 2003; Trabalon and Blais 2012). Indeed, our results show that cholesterol levels were high just after their first exogenous feeding and before juveniles moulted (10-12 days post-emergence from egg-sac; personal communication Trabalon). Hydrocarbons were used by the body to prevent desiccation and as a precursor to the synthesis of chemical signals (pheromones, kairomones (Trabalon 2013). Sphingomyelin, cholesterol and hydrocarbons were not used as energetic resources.

During the aggregated period, degradation of triglycerides and diglycerides was lower but that of free fatty acids was much higher. During dismounting, $43 \%$ of the triglyceride stock was used, increasing the diglyceride and free fatty acids stocks as for other invertebrates (Clarke et al. 1990; Sasaki et al. 1986). These variations are related to the establishment of catabolic metabolisms. A major function of free fatty acids is to maintain fluidity and permeability of membranes (Trabalon, 2011). Palmitic, stearic, oleic and linoleic acids were the dominant fatty acids in the vitellus of $P$. saltans (Trabalon et al. 2017). These fatty acids are predominant in phospholipids (Kim et al 2018) and released by phospholipases during lipolysis (Hong 2016). So the decrease of phospholipid levels from emergence to dispersal of juveniles can be related to the increasing use of free fatty acids (Kim et al 2018; Chyb et al 1999). Conversely, food intake rapidly increases the storage of lipids mainly in the form of triglycerides and leads to a decline in the stocks of diglycerides and free fatty acids 
(lipogenesis). $P$. saltans diet does not lead to an increase in phospholipids, whereas most of the lipids in vertebrates' and invertebrates diets are in the form of triglycerides, cholesterol and phospholipids (Arrese et al. 2001; Canavoso et al. 2001; Green and Glickman 1981).

The initial carbohydrate stock in the residual vitellus was not used during the aggregated period. After dismounting (D6) $50 \%$ of carbohydrate stock had been used but free glucose levels were not modified. We hypothesized that juveniles with a high level of locomotor activity for foraging would require rapid mobilisation of energetic components. Total carbohydrate levels increased after the first exogenous feeding and $84 \%$ of the initial carbohydrate stock was still present in D8 juveniles but the levels of free glucose remained stable.

In conclusion, the residual vitellus is important and enables juveniles to survive and develop until they start foraging 7-8 days after emergence. Residual vitellus is used as an energetic stock during the gregarious and dismounting periods. Variations of carbohydrate, lipid (particularly triglycerides) and protein levels induce energetic modifications. Intriguingly, only $70 \%$ of the total energetic stock had been used before the first exogenous feeding. Contrary to our hypothesis, lipids are not a priory source of energy for emerged spiderlings as for oviparous vertebrate hatchlings.

\section{References}

Ackman RG, McLeod C, Banerjee AK (1990) An overview of analyses by chromarodiatroscan TLC-FID. J Planar Chromatogr 3:450-490

Allsteadt J, Lang JW (1994) Incubation temperature affects body size and energy reserves of hatchling American alligators (Alligator mississippiensis). Physiol Zool 68(1):76-97

Andersen SO (1979) Biochemistry of the insect cuticle. Annu Rev Entomol 24:29-61 
Ar A, Arieli B, Belinsky A, Yom-Tov Y (1987) Energy in avian eggs and hatchlings: utilization and transfer. J Exp Zool 1:151-164

Arrese EL, Canavoso LE, Jouni ZE, Pennington JE, Tsuchida K, Wells MA (2001) Lipid storage and mobilization in insects: current status and future directions. Insect Biochem Molec Biol 31:7-17

Bednarek AW, Sawadro MK, Nicewicz T, Babczynska AI (2019) Vitellogenins in the spider Parasteatoda tepidariorum - expression profile and putative hormonal regulation of vitellogenesis. BMC Developmental Biol 19(4):1-19

Beningher PG, Lucas A (1984) Seasonal variations of the major lipid classes in relation to the reproductive activity of two species of clams raised in a common habitat: Tapes decussatus L. (Jeffreys) and Tapes philippinarum (Afams \& Reeve). J Exp Mar Biol Ecol 79:79-90

Boctor FN, Kamel MY (1976) Purification and characterization of two lipovitellins from eggs of the tick, Dermacentor andersoni. Insect Biochem 6:233-240

Boctor FN, Kamel MY, Sidrak W (1986) Biochemical studies on tick embryogenesis: lipovitellin and protease activity in Dermacentor andersoni (Acari: Ixodidae). J Med Entomol 23: 429-432

Brach V (1978) Social behavior in the pseudoscorpion Paratemnus elongatus (banks) (pseudoscorpionida: atemnidae). Insect Soc Paris 25:3-11

Bradford MM (1976) A rapid and sensitive method for the quantification of microgram quantities of protein utilizing the principle of protein-dye binding. Anal Biochem 72:248254

Bronstein PM (1982) Breeding, paternal behavior, and their interruption in Betta splendens. An Learn Behav 10(2):145-151

Canavoso LE, Jouni ZE, Karnas KJ, Pennington JE, Wells MA (2001) Fat metabolism in insects. Annu Rev Nutr 21:23-46 
Carr AF, Ogren L (1960) The ecology and migrations of sea turtles. 4. The green turtle in the Caribbean Sea. Bull Am Mus Not His 121:1-48

449

Chappell MA, Shoemaker VH, James DN, Maloney SK, Bucher TL (1993) Energetics of 450 foraging in breeding Adelie Penguins. Ecology 74(8):2450-2461

451

452

453

454

455

456

457

458

459

460

461

462

463

464

465

Chen L, Jiang H, Zhou Z, Li K, Deng GY, Liu Z (2004) Purification of vitellin from the ovary of Chinese mitten-handed crab (Eriocheir sinensis) and development of an antivitellin ELISA. Comp Biochem Physiol B 138:305-311

Chen Z, Corlett RT, Jiao X, Liu S, Charles-Dominique, T., Zhang S, Li H, Lai R, Long C, Quan R (2018) Prolonged milk provisioning in a jumping spider. Science 362:1052-1055

Cheong SP, Huang J, Bendena WG, Tobe SS, Hui JH (2015) Evolution of ecdysis and metamorphosis in arthropods: the rise of regulation of juvenile hormone. Integr Comp Biol $55(5): 878-890$

Chino H (1997) Physiological significance of lipid transport by lipophorin for long distance flight in insects. Comp Biochem Physiol B 117:455-461

Chinzei Y, Chino H, Takahashi K (1983) Purification and properties of vitellogenin and vitellin from a tick, Ornithodoros moubata. J Comp Physiol B 152:13-21

Chinzei Y, Yano I (1985) Fat body is the site of vitellogenin synthesis in the soft tick, Ornithodoros moubata. J Comp Physiol B 155:671-678

Chyb S, Raghu P, Hardie RC (1999) Polyunsaturated fatty acids activate the Drosophila lightsensitive channels TRP and TRPL. Letters Nature 397:255-259

Clarke A, Brown JH, Holmes LJ (1990) The biochemical composition of eggs from Macrobrachium rosenbergii in relation to embryonic development. Comp Biochem Physiol B 95:505-511

Congdon JD, Gibbons JW (1989) Posthatching yolk reserves in hatchling american alligators. Herpetologica 45:305-309 
472 Cunningham M, Pollero R, Gonzalez A (1994) Lipid circulation in spiders. Transport of 473 phospholipids, free acids and triacylglycerols as the major lipid clases by a high-density 474 lipoprotein fraction isolated from plasma of Polybetes pythagoricus. Comp Biochem $475 \quad$ Physiol B 109:333-338

476 Cunningham M, Pollero RJ (1996) Characterization of lipoprotein fractions with high content 477 of hemocyanin in the hemolymphatic plasma of Polybetes pythagoricus. J Exp Zool $274: 275-280$

De Almeida RFM, Fedorov A, Prieto M (2003) Sphingomyelin / Phosphatidylcholine / Cholesterol Phase Diagram: Boundaries and Composition of Lipid Rafts. Biophys J 85(4):2406-2416

Dhadialla TS, Raikhel AS (1990) Biosynthesis of mosquito vitellogenin. J Biol Chem 256:9924-9933

Donohue KV, KKhalil SMS, Mitchell RD, Sonenshine DE, Roe RM (2008) Molecular characterization of the major hemelipoglycoprotein in ixodid ticks. Insect Mol Biol 17(3):197-208

Fagotto F (1990) Yolk degradation in tick eggs: 1. Occurrence of a cathepsin L-like acid proteinase in yolk spheres. Arch Insect Biochem and Physiol 14:217-235

Farley R (2005) Developmental changes in the embryo, pronymph, and first molt of the Scorpion Centruroides vittatus (Scorpiones: Buthidae). J Morphol 265:1-27

491 Fredrickson DS, Gordon RSJr (1958) Transport of fatty acids. Am J Physiol 38:585-630

492 Garcia F, Cunningham M, Soulages JL, Garda HA, Pollero RJ (2006) Structural 493 characterization of the lipovitellin from the shrimp Macrobrachium borellii. Comp Biochem Physiol B 145:365-370 
495 Garcia-Guerrero M, Racotta IS, Villarreal H (2003) Variation in lipid, protein, and 496 carbohydrate content during the embryonic development of the crayfish Cherax 497 quadricarinatus (Decapoda: Parastacidae). J Crustacean Biol 23:1-6

498

499

500

501

502

503

504

505

506

507

508

509

510

511

512

513

514

515

516

517

518

Green PH, Glickman RM (1981) Intestinal lipoprotein metabolism. J Lipid Res 22(8): 1153-

$$
1173
$$

Gudderra NP, Sonenshine DE, Apperson CS, Roe RM (2002) Tissue distribution and characterization of predominant hemolymph carrier proteins from Dermacentor variabilis and Ornithodoros parkeri. J Insect Physiol 48:161-170

Hahn NS, Mattiesen FA (1993) Notas biológicas sobre Paratemnus minor (Pseudoscorpiones, Atemnidae). Rev Bras Biol 53:571 -574

Heras H, González Baró MR, Pollero RJ (2000) Lipid and fatty acid composition and energy partitioning during embryo development in the shrimp Macrobrachium borellii. Lipids $35: 645-651$

Hong CY, Han C, Chao L (2016) Nonspecific binding domains in lipid membranes induced by Phospholipase A2. Langmuir 32:6991-6999

Kawazoe, I., Jasmani, S., Shih, T., Suzuki, Y., Aida, K. (2000) Purification and characterization of vitellin from the ovary of kuruma prawn, Penaeus japonicus. Fish Sci

$$
66,390-396
$$

Kim KW (2000) Trophic egg laying in the spider, Amaurobius ferox: mother-offspring interactions and functional value. Behav Process 50:31-42

Kim KW, Horel A (2010) Matriphagy in the spider Amaurobius ferox (Araneidae, Amaurobiidae): an example of mother-offspring interactions. Ethology 104(2):1021-1037

Kim Y, Ahmed S, Stanley D, An C (2018) Eicosanoid-mediated immunity in insects. Develop Comp Immunol 83:130-143 
519 Kraemer JE, Bennett SH (1981) Utilization of post-hatchling yolk in the loggerhead sea turtles, Caretta caretta. Herpetologica 2:406-411

521

Laemmli UK (1970) Cleavage of structural proteins during the assembly of the head of bacteriophage T4. Nature 227:680-685.

Laino A, Cunningham M, Heras H, Garcia F (2011) Isolation and characterization of two vitellins from eggs of the spider Polybetes pythagoricus (Araneae: Sparassidae). Comp Biochem Physiol B 158:142-148

Laino A, Cunningham M, Costa FG, Garcia F (2013) Energy sources from the eggs of the wolf spider Schizocosa malitiosa: isolation and characterization of lipovitellins. Comp Biochem Physiol B 165:172-180

Lambson R.O. (1970) An electron microscope study of the entodermal cells of the yolk sac of the chick during incubation and after hatching. Am J Anat 129:1-20

Lubzens E, Ravid T, Khayat M, Daube N, Tietz A (1997) Isolation and characterization of the high-density lipoproteins from the hemolymph and ovary of the penaeid shrimp Penaeus semisulcatus (de Haan): apoproteins and lipids. J Exp Zool 278:339-348

Marlen M, Fisher RU (1999) Parental investment in the red-eared slider turtle, Trachemys scripta elegans. J Herpetol 33:306-309

Martin-Creuzburg D, Westerlund SA, Hoffmann KH (2007) Ecdysteroid levels in Daphnia magna during a molt cycle: determination by radioimmunoassat (RIA) and liquid chromatography-mass spectrometry (LC-MS). Gen Comp Endocrinol 151:66-71

Mac Arthur R, Wilson EO (2001) The theory of Island Biogeograpgy. Princeton University Press

McAlister WH (1960) Early growth rates in offspring from two broods of Vejovis spinigerus Wood. Texas J Sci 17:307-312 
543 Merzendorfer H, Zimoch L (2003) Chitin metabolism in insects: structure, function and regulation of chitin synthases and chitinases. J Exp Biol 206:4393-4412

545 Noble RC, Ogunyemi D (1989) Lipid changes in the residual yolk and liver of the chick 546 immediately after hatching. Bio Neo 56:228-236

547 Noga AA, Vance DE (2003) A gender specific role for phosphatidylethanolamine N548 methyltransferase - derived phosphatidylcholine in the regulation of plasma high density and very low density lipoproteins in mice. J Biol Chem 278(24):21851-21859

550

551

552

553

554

555

556

557

558

559

560

561

562

563

564

565

566

Noga AA, Zhao Y, Vance DE (2002) An unexpected requirement for phosphatidylethanolamine N-methyltransferase in the secretion of yery low density lipoproteins. J Biol Chem 277(44):42358-42365

Nowak R (1996) Neonatal survival: contributions from behavioural studies in sheep. Appl Anim Behav Sci 49:61-72

Nowak R, Poindron P (2006) From birth to colustrum: early steps leading to lamb survival. Reprod Nutr Dev 46:431-446

Noy Y, Sklan D (1998) Yolk utilization in the newly hatched poult. Br Poult Sci 39:446-451

Noy Y, Sklan D (1999) Energy utilization in newly hatched chicks. Poult Sci 78:1750-1756

Planka ER (1970) On r and K selection. Am Nat 104: 592-597

Polis GA (1990) The biology of Scorpions. Stanford University Press, Stanford California

Pourié G, Trabalon M (1999) Relationships among food and contact signals in experimental group-living Young of Tegenaria atrica. Arch Insect Biochem Physiol 42(3):186-197

Pourié G, Trabalon M (2003) The role of 20-hydroxyecdysone on the control of spider vitellogenesis. Gen Comp Endocrinol 131:250-257

Qu YF, Zhao SZ, Jiang XF, Lin LH, Ji X (2019) Can snakes use yolk reserves to maximize body size at hatching? Curr Zool 1-5. doi: 10.1093/cz/zoy098 
Radder RS, Warner DA, Cuervo JJ, Shine R (2007) The functional significance of residual yolk in hatchling lizards Amphibolurus muricatus (Agamidae). Funct Ecol 21:302-309

Romero S, Laino A, Arrighetti F, Garcia CF, Cunningham M (2019) Vitellogenesis in spiders: first analysis of protein changes in different reproductive stages of Polybetes pythagoricus. J Comp Physiol B 189(3-4):335-350

Rowe CL (2018) Standard metabolic rates of early life stages of the diamond back terrapin (Malaclemys terrapin), an estuarine turtle, suggest correlates between life history changes and the metabolic economy of hatchlings. Zool 127:20-26

Ruhland F, Chiara V, Trabalon M (2016a) Age and egg-sac loss determine maternal behaviour and locomotor activity of wolf spiders (Araneae, Lycosidae). Behav Process

$$
132: 57-65
$$

Ruhland F, Pétillon J, Trabalon M (2016b) Physiological costs during the first maternal care in the wolf spider Pardosa saltans (Araneae, Lycosidae). J Insect Physiol 95:42-50

Sasaki GC, Capuzzo JM, Biesiot P (1986) Nutritional and bioenergetics considerations in the development of the American lobster Homarus americanus. Can J Fish Aquat Sci 43:23112319

Silas EG, Vijayakumaran M, Rajagopalan M (1984) Yolk utilization in the egg of the olive ridley Lepidorhelys olivarea. Bull Cent Mar Fislz Res Inst 35:22-33

Sloggett JJ, Lorenz MW (2008) Egg composition and reproductive investment in aphidophagous ladybird beetles (Coccinellidae: Coccinellini): egg development and interspecific variation. Physiol Entomol 33(3):200-208

Slotte JP, Ramstedt B (2007) The functional role of sphingomyelin in cell membranes. Eur J Lipid Sci Technol 109:977-981

Spector AA (1984) Plasma lipid transport. Clin Physiol Biochem 2(23):123-134 
591

592

593

594

595

596

597

598

599

600

601

602

603

604

605

606

607

608

609

610

611

612

613

614

615

Tatchell RJ (1971) Electrophoretic studies on the proteins of the hemolymph, saliva and eggs of the cattle tick, Dermacentor variabilis. Insect Biochem 1:47-55

Trabalon M (2011) Agonistic interactions, cuticular and hemolymphatic lipid variations during the foraging period in spider females Brachypelma albopilosa (Theraphosidae). J Insect Physiol 57:735-743

Trabalon M (2013) Chemical communication and contact cuticular compounds in spiders. In: Nentwig W (ed) Spider Ecophysiology. Springer link. pp 125-140

Trabalon M, Blais C (2012) Juvenile development, ecdysteroids and hemolymph level of metabolites in the spider Brachypelma albopilosum (Theraphosidae). J Exp Zool 00:1-12

Trabalon M, Ruhland F, Laino A, Cunningham M, Garcia F (2017) Embryonic and postembryonic development inside wolf spiders' egg sac with special emphasis on the vitellus. J Comp Physiol B DOI 10.1007/s00360-017-1120-7

Tufail M, Takeda M (2008) Molecular characteristics of insect vitellogenins. J Insect Physiol $54: 1447-1458$

Van der Hammen L (1977) A new classification of Chelicerata. Zool Meded 51:307-319

Venkatesan S, Kannan P, Rajagopalan M, Vivekanandan E (2005) Embryonic energetics in the egg of the green turtle Chelonia mydas. J Mar Biol Ass India 47(2):193-197

Webb GJW, Choquenot D, Whitehead PJ (1986) Nests, eggs, and embryonic development of Carettochelys insculpta (Chelonia: Carettochelyidae) from Northern Australia. J Zool $1: 521-550$

Weygoldt P, Siegfried H (2013) Sperm transfer and maternal care in Thelyphonus c. f. caudatus from Lombok, Indonesia (Arachnida, Uropygi, Thelyphonida). Zool Anzeiger $252: 348-349$

Williams SC (1969) Birth activities of some north american Scorpions. Proc Calif Acad Sci. 1:1-24 
616

617

618

619

620

621

622 Table 2 Lipid composition quantified by TLC-FID ( $\mu \mathrm{g} \cdot \mathrm{mg}^{-1}$ wet mass) in juvenile Pardosa

623 saltans' residual vitellus in relation to age: D0 (12 h), D2 (2 days), D4 (4 days), D6 (6 624 days) and D8 (8 days) post-emergence from egg-sac $(n=20 /$ age $)$. Mean levels were 625 compared between ages using ANOVA and post hoc Tuckey' tests (HSD). For 626 hydrocarbons, $\mathrm{F}=4.00, \mathrm{p}>0.05$; for phosphatidylcholine: $\mathrm{F}=37.46, \mathrm{p}<0.0001$; for 627

628

629

Table 1 Percentage of the four protein bands from lipovitellin of juveniles Pardosa saltans in relation to age: D-2: juveniles 2 days before emergence from egg-sac; D0: juveniles $12 \mathrm{~h}$ after emergence from egg-sac; D2: juvenile 2 days after emergence from egg-sac; D4: juvenile 4 days after emergence from egg-sac; D6: juvenile 6 days after emergence from egg-sac; D8: juvenile 8 days after emergence from egg-sac phosphatidylethanolamine: $\mathrm{F}=15.27$; $\mathrm{p}<0.0001$; for sphingomyelin: $\mathrm{F}=3.80, \mathrm{p}>0.05$. Different letters indicate a significant difference from other ages at $\mathrm{p}<0.05$ 
630

631

632

633

634

635

636

637

638

639

640

641

642

643

644

645

646

647

648

649

650

651

652

Fig 1 Post-emergence life-cycle of Pardosa saltans (Lycosidae) under laboratory conditions $\left(20 \pm 1^{\circ} \mathrm{C}, 57 \pm 1 \%\right.$ relative humidity $)$

Fig 2 Number (A) and weights (B) of Pardosa saltans juveniles after emergence from eggsacs, in relation to ages (days) and behavioural periods under laboratory conditions $\left(21 \pm 1^{\circ} \mathrm{C}\right.$, $54 \pm 1 \%$ relative humidity; $\mathrm{n}=350$ juveniles emerged from 20 egg-sacs). Mean levels were compared between ages using ANOVA and post hoc Tukey (HSD) tests: different letters indicate a significant difference from other age at $\mathrm{p}<0.05$

Fig 3 Protein concentrations (A) in juvenile Pardosa saltans' residual vitellus in relation to ages: 0 (D0), 2 (D2), 4 (D4), 6 (D6) and 8 (D8) days post-emergence ( $\mathrm{n}=20 /$ ages). Mean levels for each age were compared using ANOVA and post hoc Tukey’s (HSD) tests: different letters indicate a significant difference from other ages at $\mathrm{p}<0.05$. Electrophoresis (SDS-PAGE) analyses: $20 \mu \mathrm{g}$ of soluble protein for each well (B) and immunoblot $5 \mu \mathrm{g}$ of soluble protein for each well. Gel serves only as a guide to later show the consumption of lipovitellins throughout the different stages (C).D-2: juvenile 2 days before emergence from egg-sac, D0, D4, D6 and D8 juveniles post-emergence from eggsac, Std: standard, MW: molecular weight

Fig 4 Triglycerides (A), diglycerides (B) and free fatty acids (C) concentrations in juvenile Pardosa saltans' residual vitellus in relation to ages: 0 (D0), 2 (D2), 4 (D4), 6 (D6) and 8 (D8) days post-emergence $(n=20 / a g e s)$. Mean levels were compared between stages using ANOVA and post hoc Tukey's (HSD) tests: different letters indicate a significant difference from other age at $p<0.05$

Fig 5 Cholesterol (A) and phospholipids (B) concentrations in juvenile Pardosa saltans' residual vitellus in relation to ages: 0 (D0), 2 (D2), 4 (D4), 6 (D6) and 8 (D8) days post- 

emergence ( $n=20 /$ ages). Mean levels were compared between stages using ANOVA and post hoc Tukey's (HSD) tests: different letters indicate a significant difference from other age at $\mathrm{p}<0.05$

656

657

658

659

660

661

662

663

664

Fig 6 Carbohydrates (A) and glucose (B) concentrations in juvenile Pardosa saltans' residual vitellus in relation to ages: 0 (D0), 2 (D2), 4 (D4), 6 (D6) and 8 (D8) days post-emergence ( $n=20 /$ ages). Mean levels for each age were compared using ANOVA and post hoc Tukey's (HSD) tests: different letters indicate a significant difference from other age at $\mathrm{p}<$ 0.05. NS non-significant difference

Fig 7 Calories provided by proteins, triglycerides and carbohydrates in juvenile Pardosa saltans' residual vitellus in relation to ages: 0 (D0), 2 (D2), 4 (D4), 6 (D6) and 8 (D8) days post-emergence $(n=20 /$ ages $)$. (A) Total calories. $\mathrm{g}^{-1}$ wet mass. (B) Total calories. $\mathrm{g}^{-1}$ wet mass in percent 
Figure 1

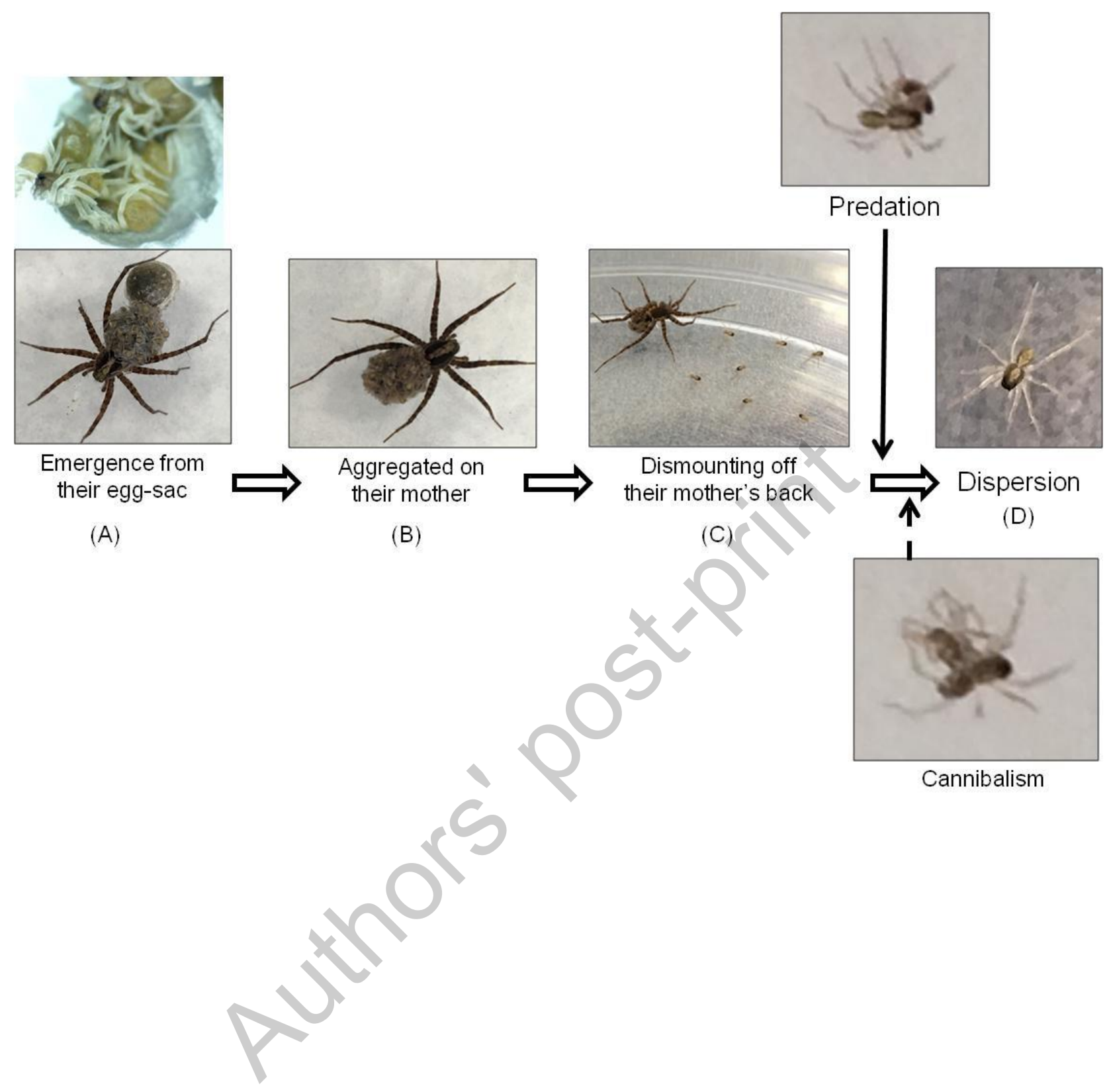


Figure 2

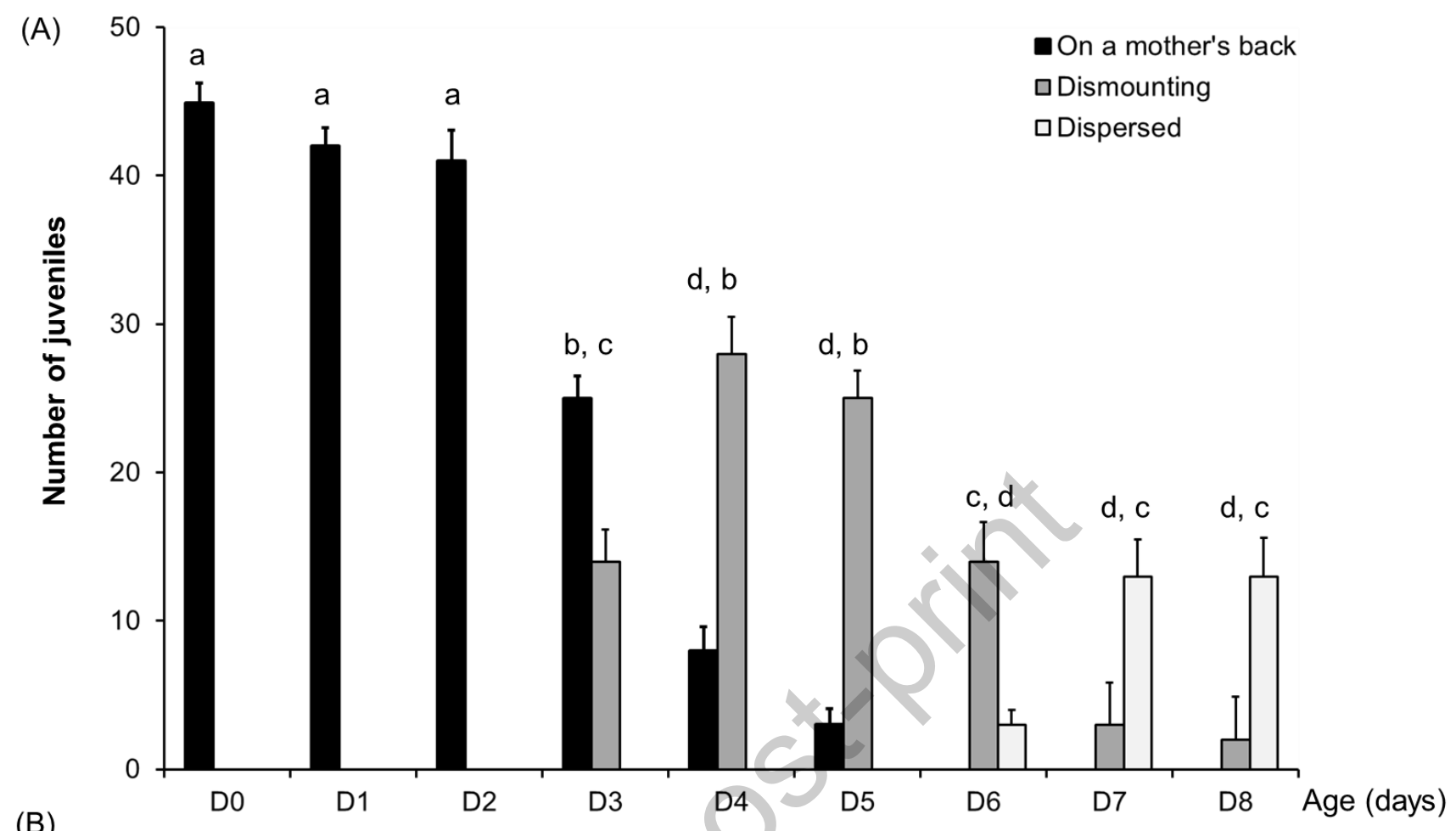

(B)

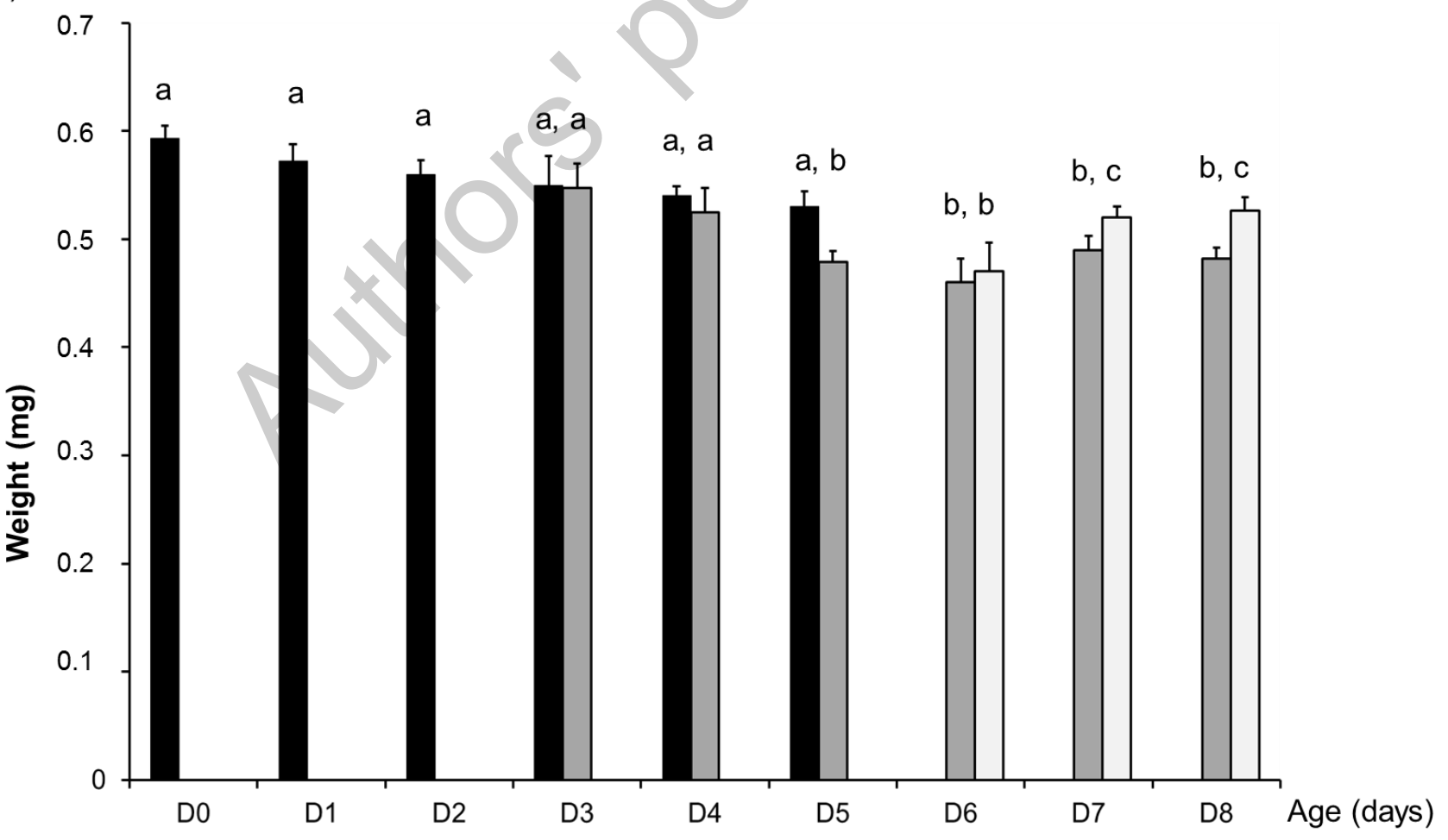


Figure 3

(A)

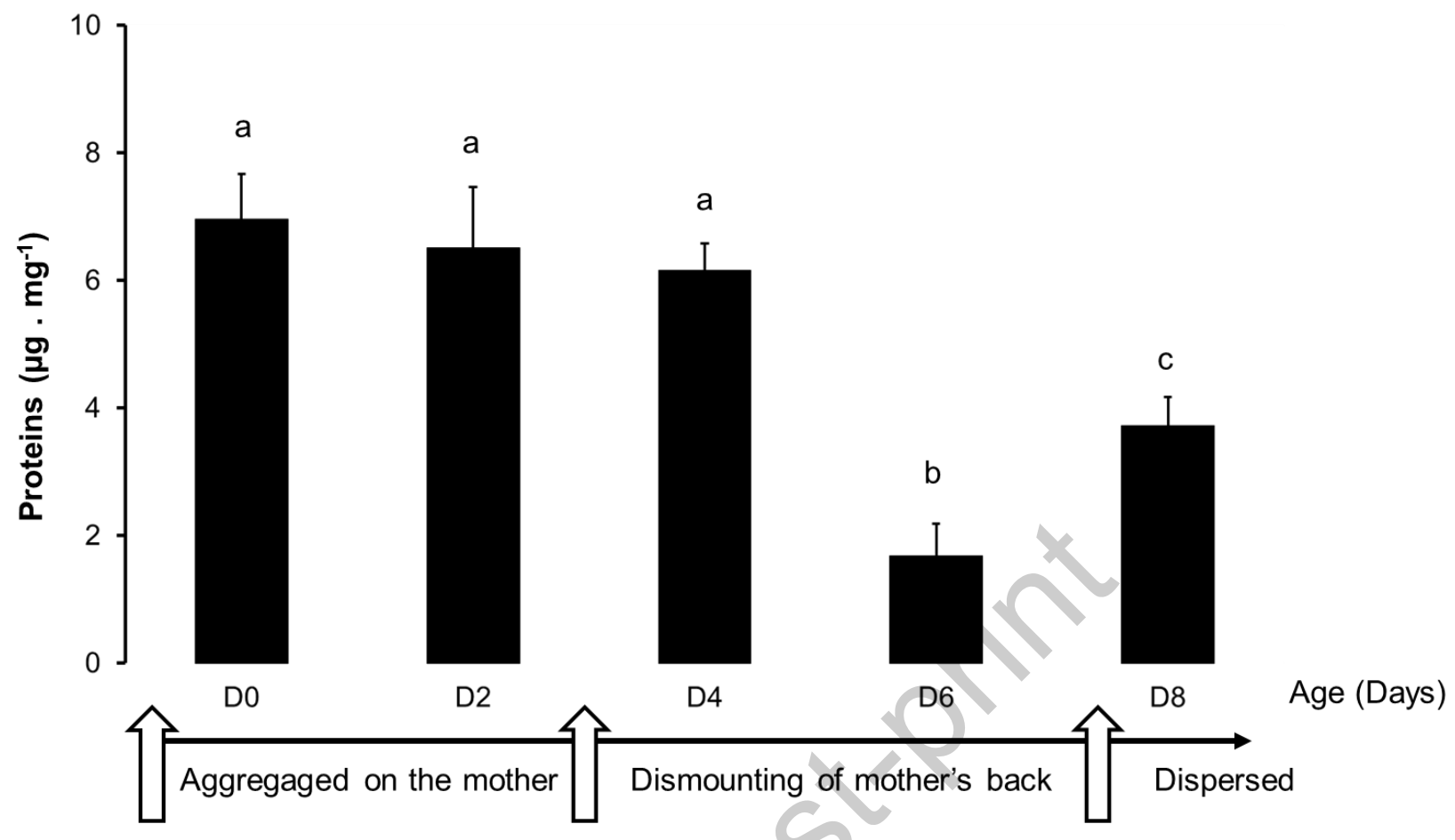

Hatching

First predation
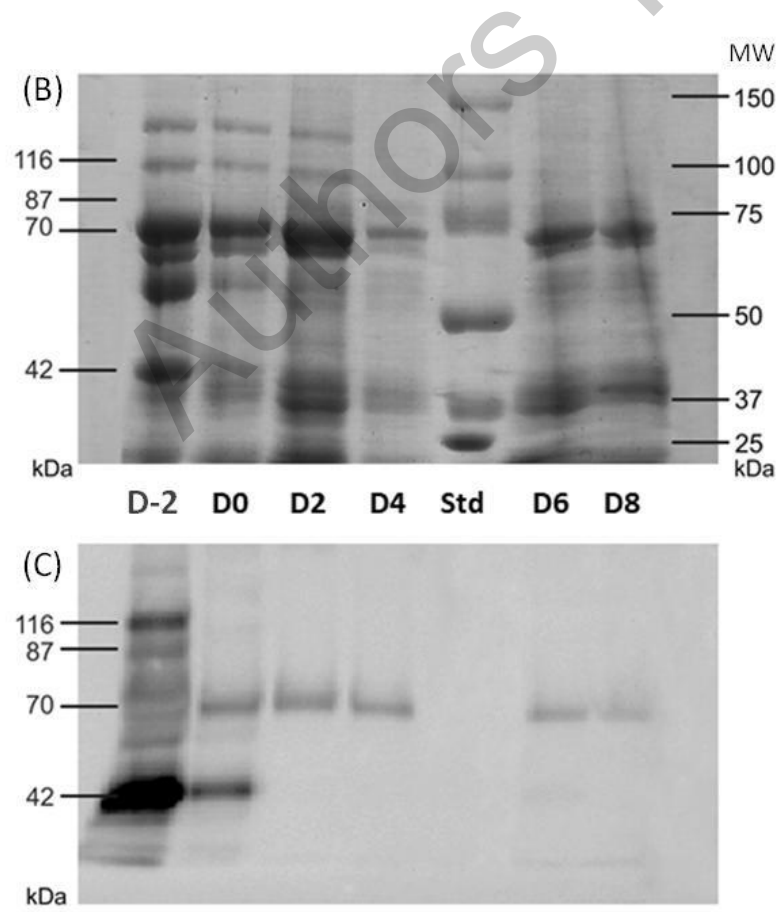
Figure 4
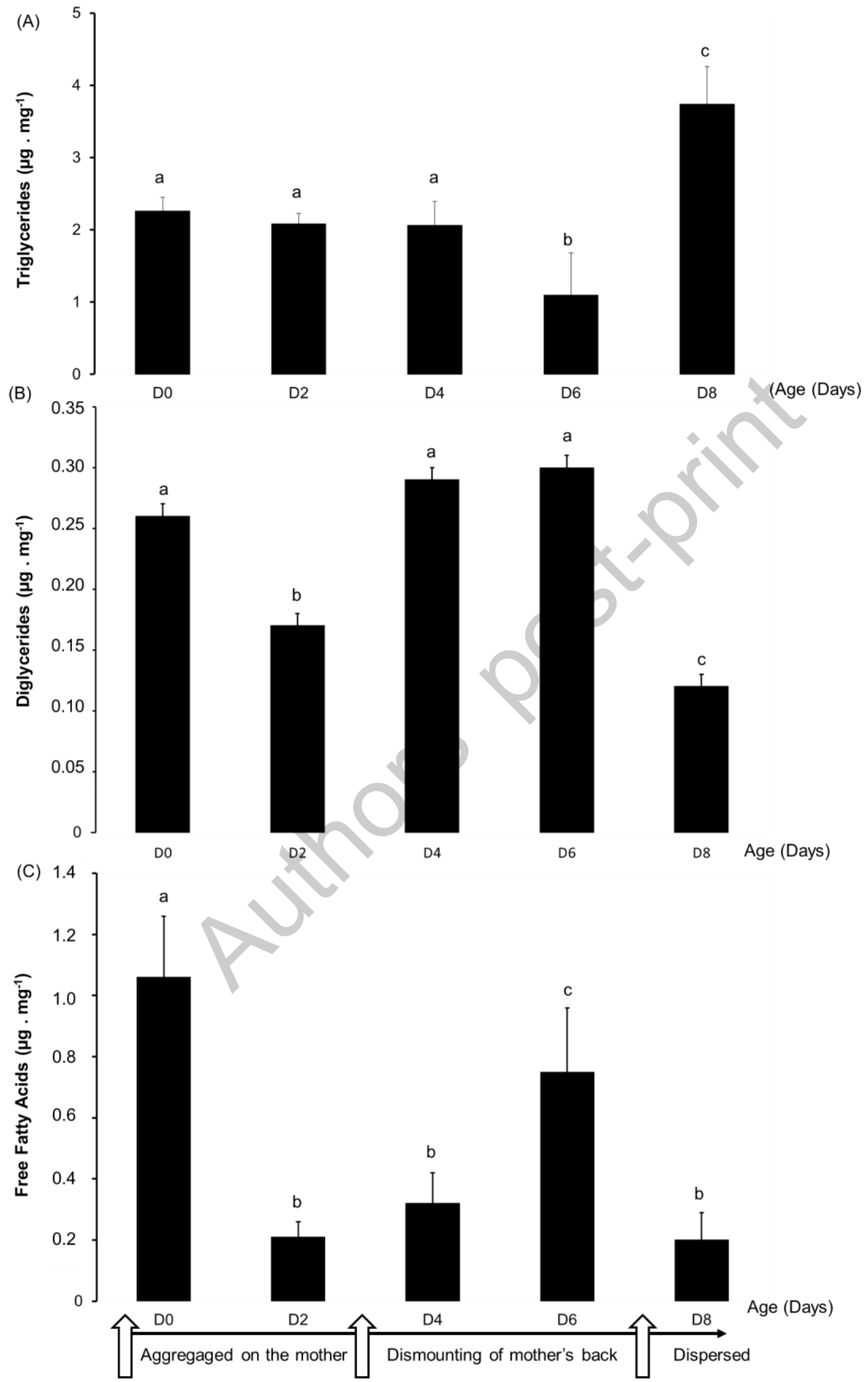
Figure 5
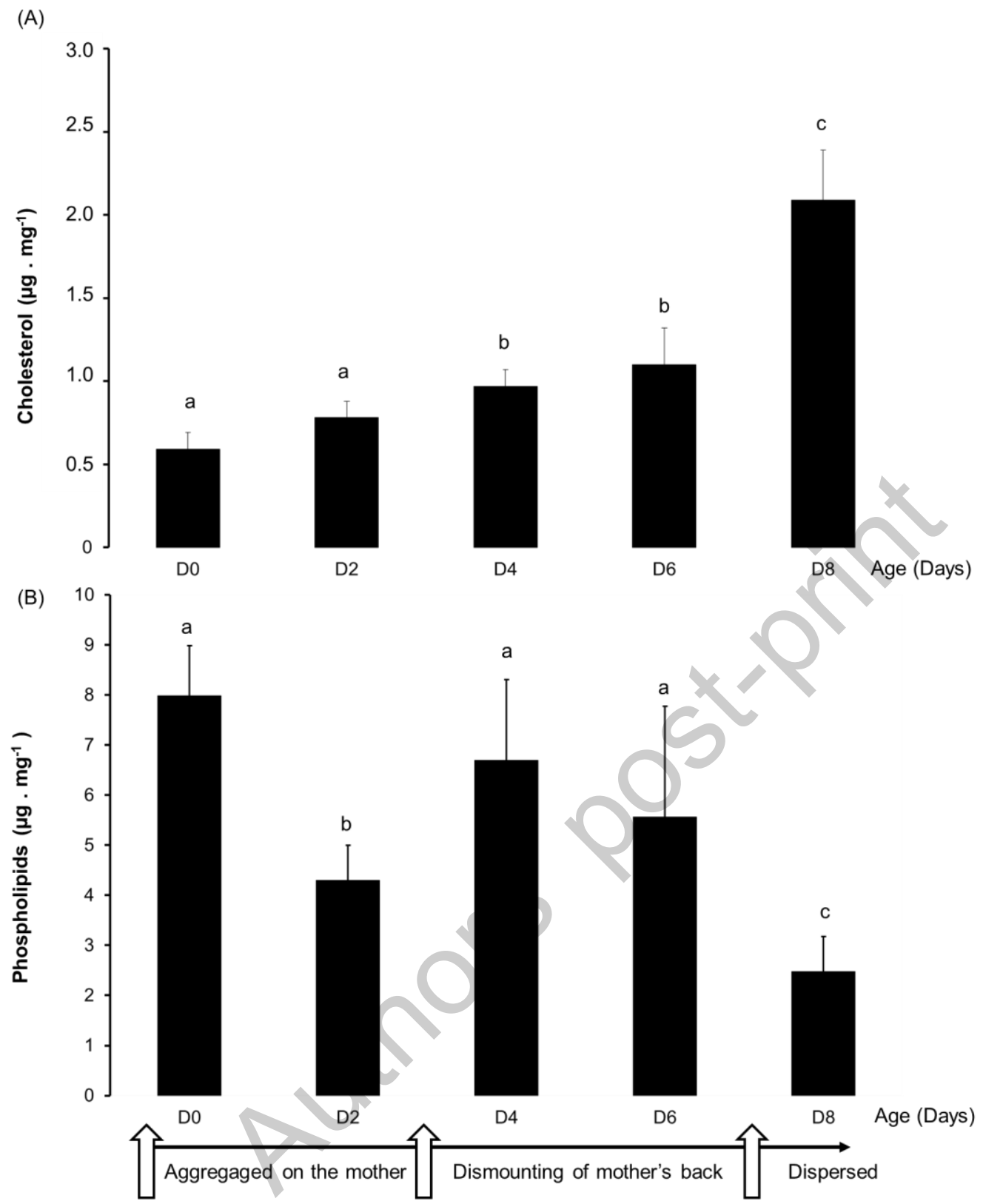

Hatching

First predation 
Figure 6
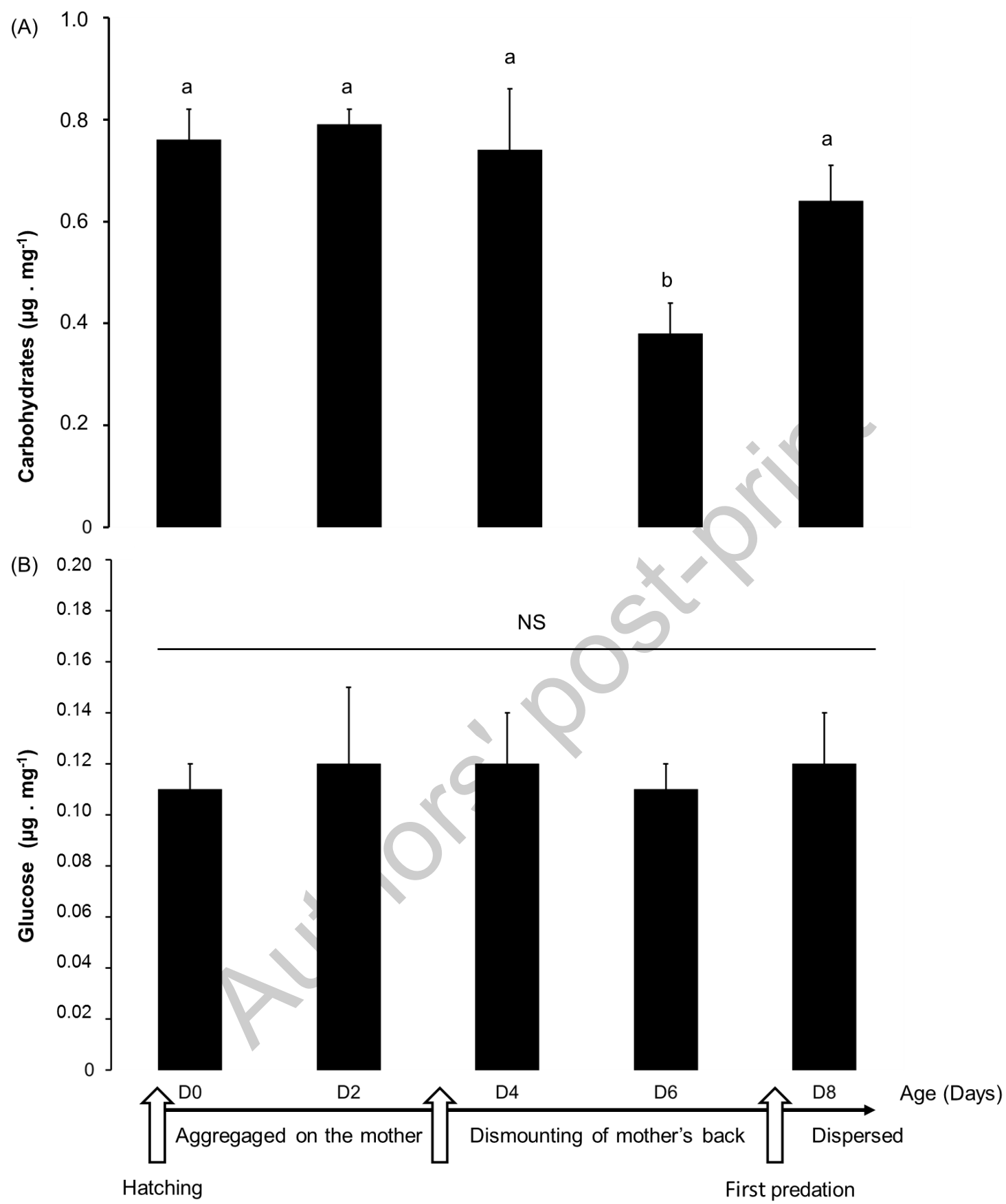
Figure 7

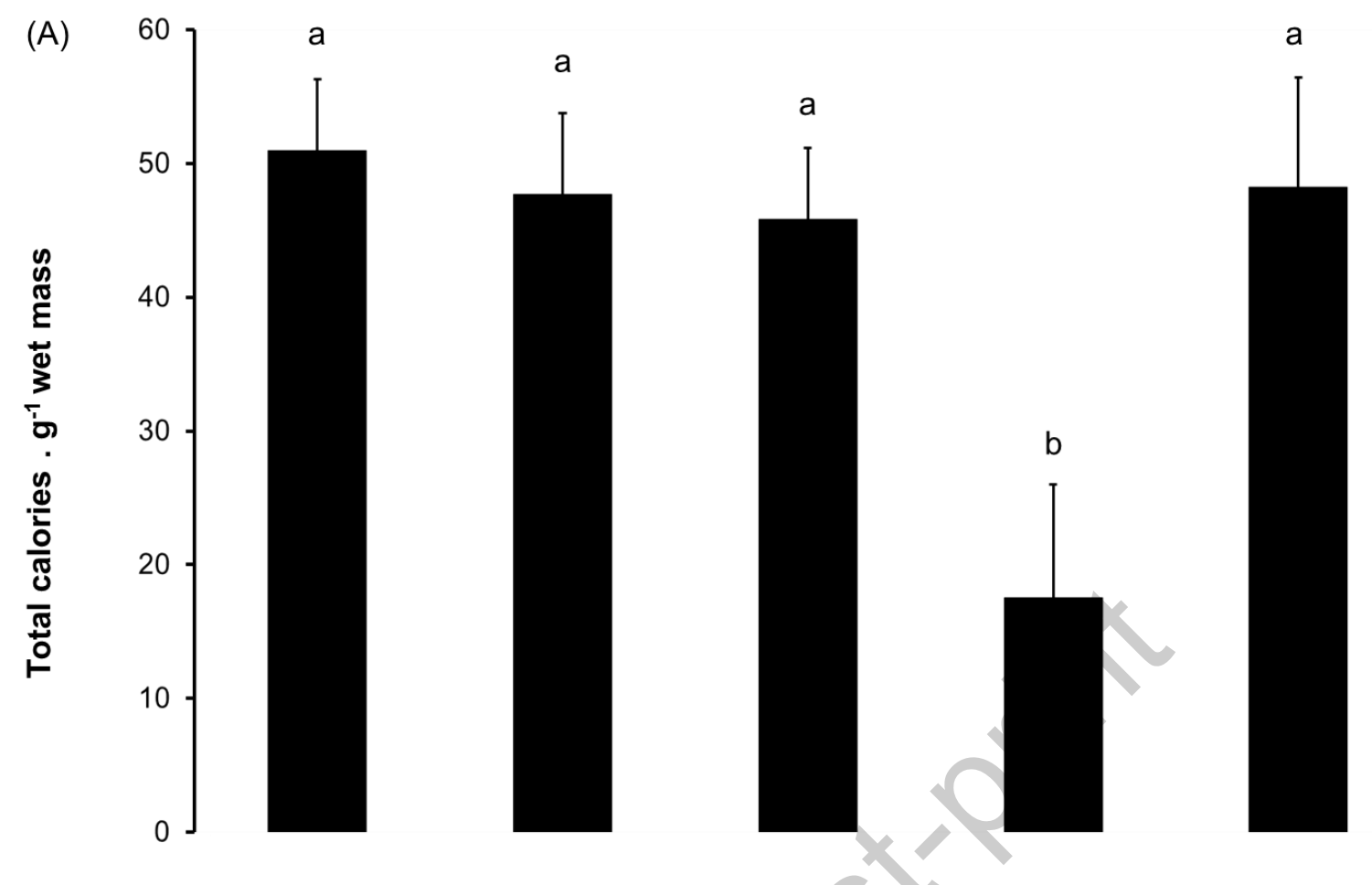

(B)

- Lipids $\square$ Carbohydrates $\square$ Proteins
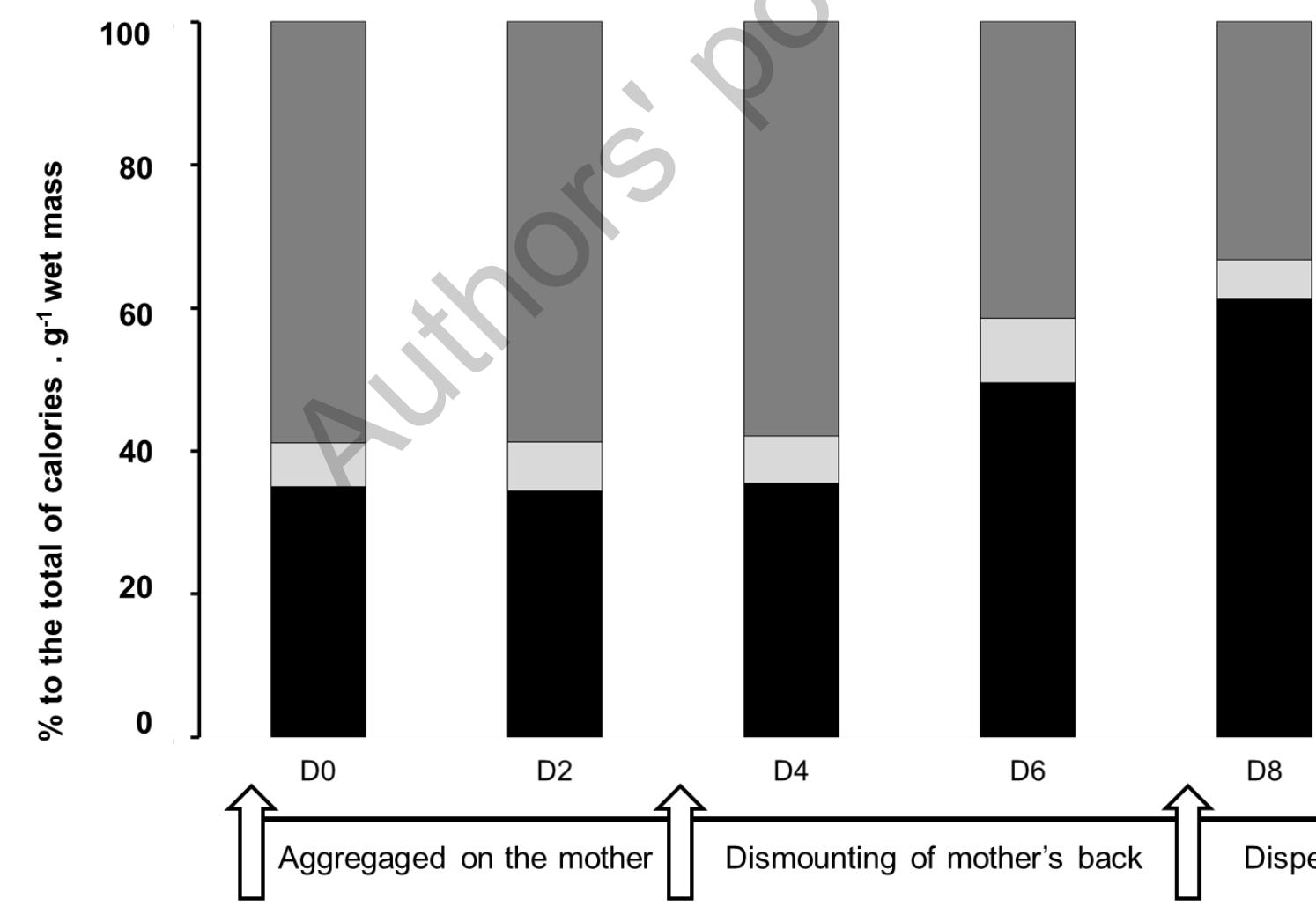

D4

D6

Dismounting of mother's back

D8 Age (Days)

Hatching

First predation 
Table 1 Percentage of the four protein bands from lipovitellin of juveniles Pardosa saltans in relation to age: D-2: juveniles 2 days before emergence from egg-sac; D0: juveniles $12 \mathrm{~h}$ after emergence from egg-sac; D2: juvenile 2 days after emergence from egg-sac; D4: juvenile 4 days after emergence from egg-sac; D6: juvenile 6 days after emergence from egg-sac; D8: juvenile 8 days after emergence from egg-sac

$\%$ / protein from lipovitellin in relation to age

\begin{tabular}{ccccccc}
\hline Proteins $(\mathrm{kDa})$ & $\mathrm{D}-2$ & $\mathrm{D} 0$ & $\mathrm{D} 2$ & $\mathrm{D} 4$ & $\mathrm{D} 6$ & $\mathrm{D} 8$ \\
\hline $\mathbf{1 1 6}$ & 100 & - & - & - & - & - \\
$\mathbf{8 7}$ & 100 & - & - & & & \\
$\mathbf{7 0}$ & 100 & 74 & 60 & 40 & 28 & 20 \\
$\mathbf{4 2}$ & 100 & 26 & - & - & - & - \\
\hline
\end{tabular}


Table 2 Lipid composition quantified by TLC-FID ( $\mu \mathrm{g} \cdot \mathrm{mg}^{-1}$ wet mass) in juvenile Pardosa saltans' residual vitellus in relation to age: D0 (12 h), D2 (2 days), D4 (4 days), D6 (6 days) and D8 (8 days) post-emergence from egg-sac $(n=20 / a g e)$. Mean levels were compared between ages using ANOVA and post hoc Tuckey' tests (HSD). For hydrocarbons, $\mathrm{F}=4.00, \mathrm{p}>0.05$; for phosphatidylcholine: $\mathrm{F}=37.46, \mathrm{p}<0.0001$; for phosphatidylethanolamine: $\mathrm{F}=15.27 ; \mathrm{p}<0.0001$; for sphingomyelin: $\mathrm{F}=3.80, \mathrm{p}>0.05$. Different letters indicate a significant difference from other ages at $\mathrm{p}<0.05$

\section{$\mu \mathrm{g}$ of lipids . $\mathrm{mg}^{-1}$ wet mass}

\begin{tabular}{llllll}
\hline Lipids & D0 & D2 & D4 & D6 & D8
\end{tabular}

\section{Hydrocarbons}

$0.12 \pm 0.01^{\mathrm{a}}$

$0.15 \pm 0.03^{\mathrm{a}}$

$0.14 \pm 0.01^{\mathrm{a}}$

$0.18 \pm 0.05^{\mathrm{a}}$

$0.15 \pm 0.01^{\mathrm{a}}$

\section{Phospholipids}

- Phosphatidylcholine

$3.61 \pm 0.20^{\mathrm{a}}$

$1.92 \pm 0.03^{\mathrm{b}}$

$3.63 \pm 0.76^{\mathrm{a}}$

$2.43 \pm 0.58^{b}$

$1.11 \pm 0.03^{\mathrm{c}}$

- Phosphatidylethanolamine

$$
3.46 \pm 0.69^{\mathrm{a}}
$$

$1.73 \pm 0.03^{\mathrm{b}}$

$2.11 \pm 0.56^{\mathrm{b}}$

$2.02 \pm 0.90^{\mathrm{b}}$

$0.97 \pm 0.03^{\mathrm{c}}$

\section{Sphingolipids}

Sphingomyelin

$0.92 \pm 0.10^{\mathrm{a}}$

$0.65 \pm 0.01^{\mathrm{a}}$

$0.96 \pm 0.29^{\mathrm{a}}$

$1.11 \pm 0.73^{\mathrm{a}}$

$0.40 \pm 0.01^{\mathrm{a}}$ 